\title{
Egészségügyi Világszervezet Dohányzás-ellenőrzési Keretegyezmény: magyar országjelentések
}

\author{
World Health Organization Framework Convention on Tobacco \\ Control: Hungarian reports
}

\author{
Szerzők: Demjén Tibor, Kiss Judit $\bowtie$, Viski Dorottya \\ Nemzeti Egészségfejlesztési Intézet
}

Beküldve: 2017.02.07.

doi: 10.24365/ef.v58i1.144

\begin{abstract}
Kulcsszavak: dohányzás, Egészségügyi Világszervezet Dohányzás-ellenőrzési Keretegyezmény, országjelentés
\end{abstract}

Keywords: smoking, World Health Organization Framework Convention on Tobacco Control, country report

\section{BEVEZETÉS}

Az Egészségügyi Világszervezet (a továbbiakban: WHO) Dohányzás-ellenőrzési Keretegyezménye (a továbbiakban: FCTC) az első nemzetközi közegészségügyi egyezmény, melynek célja a jelenlegi és jövőbeni generációk védelme, a dohányzás és a dohányfüstnek való kitettség súlyos egészségügyi, gazdasági és társadalmi következményeinek csökkentése. A Keretegyezményhez csatlakozó Részes Felek vállalják, hogy kétévente jelentést készítenek annak érdekében, hogy bemutassák országuk dohányzáspolitikáját, a dohányzás visszaszorításáért tett intézkedéseket, a dohányzással összefüggésbe hozható adatokat és statisztikákat. A Keretegyezmény Magyarországon a 2005. évi III. törvénnyel lépett hatályba, ezért 2007-ben, 2010-ben, 2012-ben, 2014ben és 2016-ban készült országjelentés, amelyeket az 1. táblázat tartalmaz. Jelen összefoglaló célja bemutatni a dohányzással összefüggő egészségterheket, a Keretegyezményt és jelentési rendszerét, valamint egy példát a jelentésekből hozzáférhető adatokra, információkra.

\section{STATISZTIKAI KITEKINTÉS A WHO FCTC TÜKRÉ- BEN}

A dohányzás világszerte a leginkább megelőzhető haláloknak számít, ennek ellenére évente közel 6 millió ember haláláért felelős világszerte és több mint 500 milliárd dollár értékű gazdasági kárt okoz. ${ }^{1,2}$ Az Európai Unióban a korai elhalálozás kiváltó okai között is a dohánytermékek fogyasztása áll első helyen: évente közel 700000 ember haláláért felelős. A dohányzók 50\%-a 65 éves kora előtt hal meg, nem dohányzó kortársaiknál átlagosan 14 évvel korábban. ${ }^{3}$ Emellett a dohányzók nagyobb valószínűséggel szenvednek a káros egészséghatások következményeitől is, beleértve a szív- és érrendszeri, a légző szervi és a daganatos megbetegedéseket.

A WHO legfrissebb adatai alapján 2015-ben 1,1 milliárd 15 év feletti ember dohányzott világviszonylatban. ${ }^{4}$ A nemzetközi statisztikai helyzetképet a WHO egyik legfrissebb, 2013-ban közreadott időszaki kiadványa mutatja be a leghitelesebb adatokkal alátá- 
masztott, WHO FCTC országjelentések összegzése alapján. ${ }^{5}$ Ahogyan azt az 1 . ábra is jelzi, a dohányzás elterjedtsége a WHO régiók tekintetében az Európai
Régióban volt a legmagasabb: a 15 év feletti európai lakosság 28\%-a dohányzott 2013-ban.

1. táblázat: Magyarország országjelentései

\begin{tabular}{|c|c|c|}
\hline Jelentés & Benyújtás ideje & Határozat száma és címe \\
\hline első jelentés & 2007. március 19. & $\begin{array}{l}\text { 2040/2007. (III. 13.) Korm. határozat Az Egészségügyi Világszervezet Dohány- } \\
\text { zás-ellenőrzési Keretegyezmény } 21 \text {. Cikke szerinti jelentés jóváhagyásáról6 }\end{array}$ \\
\hline második jelentés & 2010. február 19. & $\begin{array}{l}\text { Korm. határozat Az Egészségügyi Világszervezet Dohányzás-ellenőrzési Ke- } \\
\text { retegyezmény 21. Cikke szerinti jelentés jóváhagyásáról }\end{array}$ \\
\hline harmadik jelentés & 2012. április 27. & $\begin{array}{l}\text { 1134/2012. (V. 3.) Korm. határozat Az Egészségügyi Világszervezet Dohány- } \\
\text { zás-ellenőrzési Keretegyezmény } 21 \text {. Cikke szerinti jelentés jóváhagyásáról }{ }^{7}\end{array}$ \\
\hline negyedik jelentés & 2014. április 18. & $\begin{array}{l}\text { 1244/2014. (IV. 18.) Korm. határozat Az Egészségügyi Világszervezet Do- } \\
\text { hányzás-ellenőrzési Keretegyezmény } 21 \text {. cikke szerinti jelentés jóváhagyásá- } \\
\text { ról }^{8}\end{array}$ \\
\hline ötödik jelentés & 2016. április 22. & $\begin{array}{l}\text { 1354/2016. (VII. 6.) Korm. határozat az Egészségügyi Világszervezet Dohány- } \\
\text { zás-ellenőrzési Keretegyezményének } 21 \text {. cikke szerinti jelentés jóváhagyásá- } \\
\text { ról }^{9}\end{array}$ \\
\hline
\end{tabular}

Forrás: A Dohányzás Fókuszpont saját készítésú táblázata (2017)

1. ábra: A dohányzás gyakorisága (\%) a WHO régióiban (2013)

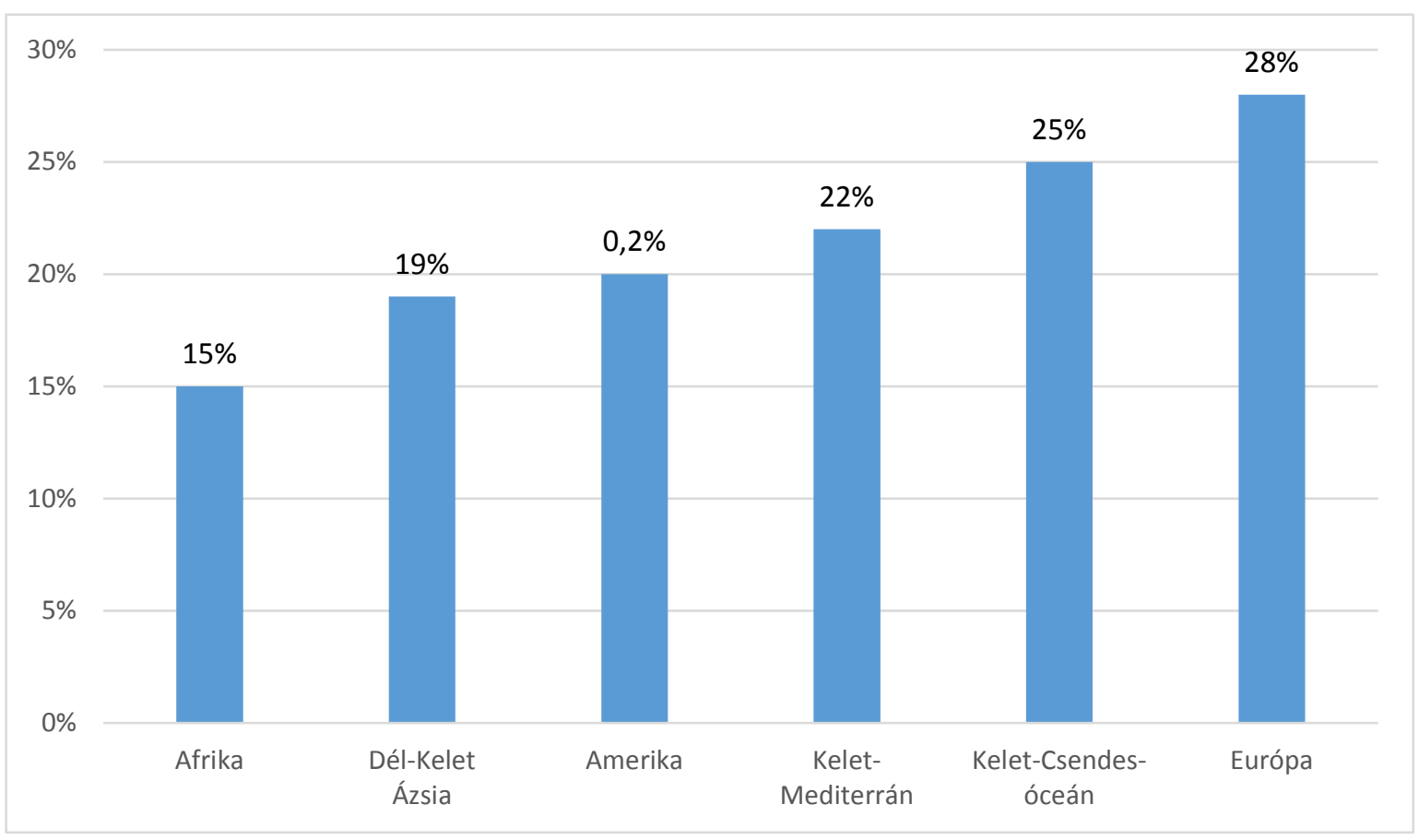

Forrás: European Tobacco Control Status Report 2013. WHO Regional Office for Europe, 2013 
Ami az időbeli tendenciákat illeti, elmondható, hogy világszerte csökken a dohányzók száma, a regionális bontást tekintve a WHO Kelet- Mediterrán és Afrikai régiójában viszont nőtt a dohányzás prevalenciája. ${ }^{10}$

A dohányzásnak tulajdonítható halálozás százalékos részarányai az egyes WHO régiók szerinti bontásban a 2. táblázatban figyelhetőek meg. A táblázat adataiból jól látható, hogy a dohányzásnak tulajdonítható halálozás az európai régióban a legmagasabb (16\%), míg az afrikaiban a legalacsonyabb (3\%), ami a prevalencia adatok alakulásához hasonló trendet jelez.

Az európai országok felnőtt lakosságára vonatkozó adatok kapcsán a WHO 2012-es Európai Egészségjelentésében az európai lakosság dohányzási gyakoriságait tekintve a 15 év feletti, rendszeresen dohányzó férfiak esetében a 13., míg a nők esetében a rendkívül kedvezőtlen 3. helyen állt Magyarország, ahogyan az a 2. ábrán is jól látható. ${ }^{11}$

Az Európai Unió tagországaival való összehasonlításhoz a WHO által becsült dohányzással összefüggő halálozás, azaz néhány, a dohányzással egyértelműen összefüggésbe hozható betegség miatti halálozás mutatóját lehet alkalmazni. Megállapítható, hogy Magyarországon a férfiak esetében a dohányzásnak tulajdonítható halálozás az európai trendeknek megfelelően csökkenő tendenciát mutatott 2005 és 2014 között, azonban még így is messze meghaladja az európai uniós tagállamok esetében előforduló arányt. Nőknél mind az európai, mind a hazai adatok alapján változatlan trend figyelhető meg, azonban a magyar halálozási arányok ebben az esetben is messze meghaladják az uniós tagállamokét. [3. ábra] ${ }^{\mathrm{i}}$

2. táblázat: A dohányzással összefüggésbe hozható halálozás (\%) a WHO régióiban (2013)

\begin{tabular}{|c|c|}
\hline WHO régió & Dohányzásnak tulajdonitható halálozás (\%) \\
\hline Európa & 16 \\
\hline Amerika & 16 \\
\hline Kelet- Csendes Óceán & 13 \\
\hline Dél- Kelet Ázsia & 10 \\
\hline Kelet- Mediterrán & 7 \\
\hline Afrika & 3 \\
\hline
\end{tabular}

Forrás: European Tobacco Control Status Report 2013. WHO Regional Office for Europe, 2013

2. ábra: A 15 év feletti, rendszeresen dohányzók részaránya az EU tagországaiban (2012)

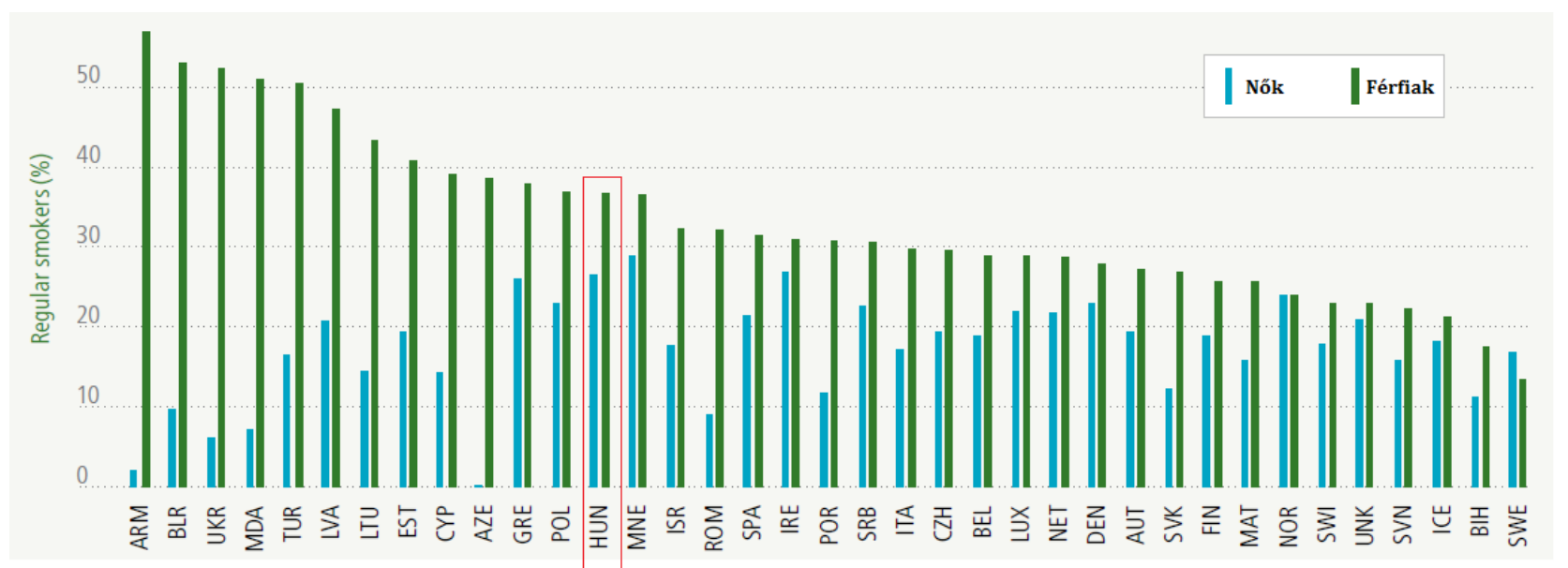

Forrás: The European Health Report 2012. WHO Regional Office for Europe, 2013

Az ábra a Nemzeti Egészségfejlesztési Intézet megjelenés alatt álló kiadványából, az „Egészségjelentés 2016” címú dokumentumból származik. 
3. ábra: A dohányzással összefüggésbe hozható halálozás alakulása Magyarországon, valamint az EU15 és az EU13 országokban (2005-2013)

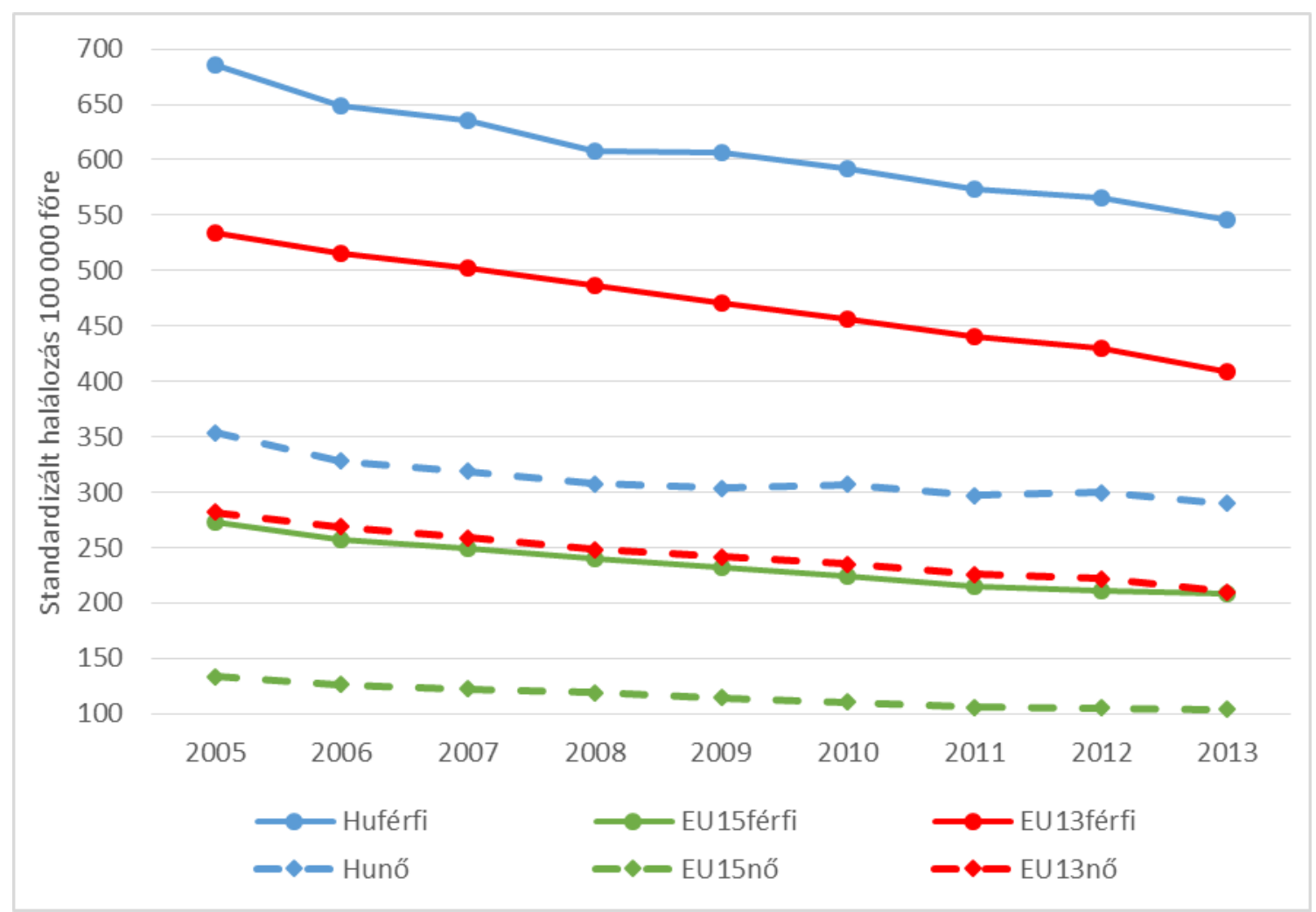

Forrás: Egészségjelentés 2016. Nemzeti Egészségfejlesztési Intézet, 2017

A dohányzás Magyarországon is súlyos népegészségügyi és nemzetgazdasági problémát jelent, a 2016-os Egészségjelentés alapján a dohányzás a második legjelentősebb viselkedési egészségkockázat. „A dohányzás a magyar lakosság összes egészségveszteségének $14 \%$-áért felelős. A férfiak esetében közel kétszer nagyobb egészségveszteséggel jár (18\%), mint nőknél (10\%). Főként a daganatos megbetegedések és a keringési rendszer betegségein keresztül fejti ki hatását, de fontos szerepet játszik a krónikus légzőszervi megbetegedések által okozott egészségveszteségek kialakulásában is."

2015-ben 22496 ember halt meg és több mint 500 ezer egészségben eltöltött életévet (DALYii) veszítettünk el, ezzel Magyarország az Európai Unió 28 tagországa között a legrosszabb helyen állt, annak ellenére, hogy 1990 óta csökkenő tendencia figyelhető meg a dohányzással összefüggő mutatókban, mind az aktív, mint a passzív dohányzás tekintetében. ${ }^{12}$

\section{AZ FCTC HÁTTERE ÉS LÉTREJÖTTÉNEK OKAI}

A fenti epidemiológiai háttérrel kapcsolatos globális egészségpolitikai kihívások hívták életre az Egészségügyi Világszervezet Dohányzás-ellenőrzési Keretegyezményét, az első olyan nemzetközi közegészségügyi egyezményt, amelynek célja a jelenlegi és jövőbeni generációk védelme, a dohányzás és a dohányfüstnek való kitettség súlyos egészségügyi, gazdasági és társadalmi következményeinek csökkentése. Az Egészségügyi Világszervezet 1996. évi negyvenkilencedik közgyúlése, felismerve, hogy a dohányzási epidémia terjedése, a cigaretta, illetve egyéb dohánytermékek fogyasztásának és termelésének világszerte tapasztalható növekedése globális probléma, határozatban kérte fel a WHO főigazgatóját egy Keretegyezmény létrehozására. Az 1999től megtartott kormányközi, az ipar meghallgatásával is kiegészített tárgyalások eredményeként,

\footnotetext{
ii Disability-Adjusted Life Year
} 
2003-ban elfogadásra került a Keretegyezmény szövege. A bizonyítékokon alapuló dohányzást visszaszorító intézkedések területén mérföldkőnek tekinthető egyezmény 40 ország aláírásával 2005. február 27-én lépett hatályba. Eddig 168 tagállam írta alá, és jelenleg 180 Részes Fél tagja az egyezménynek. ${ }^{13}$ Az egyezmény aláírása csupán az FCTC elismerését és támogatását jelenti, kötelezettséget csak a ratifikálás után jelent az aláíró tagállam számára.

A Részes Felek a Részes Felek konferenciáján kétévenként áttekintik a Keretegyezmény megvalósításának eredményeit és további feladatokat valamint kötelezettségeket írnak elő, amelyek a hatékonyabb múködést és végrehajtást szolgálják. A Keretegyezmény irányelvekkel ${ }^{14}$ és jegyzőkönyvvel ${ }^{15}$ egészült ki, amelyek célja többek között a dohányzás okozta megbetegedésekből eredő halálozási mutatók csökkentése, a gazdasági terhek enyhítése, illetve a határokon átnyúló illegális kereskedelem terjedésének megakadályozása. A Keretegyezményhez csatlakozó Részes Felek vállalják, hogy kétévente országjelentést készítenek, annak érdekében, hogy bemutassák az országuk dohányzáspolitikáját, a dohányzás visszaszorításáért tett intézkedéseket, a dohányzással összefüggésbe hozható adatokat és statisztikákat. A Keretegyezmény Magyarországon a 2005. évi III. törvénnyel lépett hatályba.

\section{AZ FCTC FELÉPÍTÉSÉRŐL}

Az egyezmény az általános elveket megfogalmazó preambulumból és 38 cikkből áll, melyek 10 nagyobb témakörre oszthatóak fel:

- 1-2. cikk: bevezetés

- 3-5. cikk: célkitúzés, vezérelvek és általános kötelezettségek

- 6-14. cikk: a dohány iránti kereslet csökkentésével kapcsolatos intézkedések

- 15-17. cikk: a dohánykínálat csökkentésével kapcsolatos intézkedések

- 18. cikk: a környezet védelme

- 19. cikk: felelősséggel kapcsolatos kérdések

- 20-22. cikk: tudományos és technikai együttmúködés és az információk közlése

- 23-26. cikk: intézményi megoldások és pénzügyi források
- 27. cikk: vitás kérdések rendezése

- 28-29. cikk: keretegyezmény továbbfejlesztése

- 30-38. cikk: záró rendelkezések

A Keretegyezmény felügyeletének, végrehajtásának ellenőrzését a Részes Felek Konferenciája (COPiii) látja el, melynek minden, a Keretegyezményt ratifikáló fél tagja. Az évente megrendezett konferencián az egyezmény technikai és pénzügyi felügyeletét végzik, emellett az irányelveket és a jegyzőkönyvek kidolgozását, valamint a végrehajtásról készült beszámolókat ismertetik a résztvevő Részes Felek.

\section{AZ ORSZÁGJELENTÉSRŐL}

A jelentések elkészítése kérdőívek kitöltését jelenti, valamint a szükséges mellékletek elkészítését igényli többek között a dohányzás prevalencia, dohányfüstmentes környezettel kapcsolatos szabályozás, adózás, illegális kereskedelem, reklám, dohánytermékek csomagolása, címkézése, dohánytermesztés, oktatás, képzés, leszokás segítés területeiről.

A Keretegyezmény Beszámolás és információcsere c. 21. cikkének 1. pontja ${ }^{16}$ előírja a tagállamok számára a jelentési kötelezettséget, melynek a tagállamok a ratifikálást követően maximum egy éven belül kötelesek megfelelni. 2012 óta minden Részes Fél kétévente jelentést készít. A Dohányzás ellenőrzési Keretegyezményt Magyarország 2004. április 7én ratifikálta, és 2005. február 27-én a 2005. évi III. törvény keretében került kihirdetésre. A magyarországi adatszolgáltatás koordinációját, a jelentés öszszeállítását a minisztérium kijelölése alapján a Dohányzás Fókuszpont (DF) végzi. A jelentés összeállítása során a DF együttmúködik az egyes minisztériumok és intézmények, így különösen az Emberi Erőforrások Minisztériuma, a Földmúvelésügyi Minisztérium, a Nemzetgazdasági Minisztérium, a Nemzeti Fejlesztési Minisztérium, a Nemzeti Dohánykereskedelmi Nonprofit Zrt. és az Igazságügyi Minisztérium kijelölt kapcsolattartóival.

A jelentések elkészítésének célja, hogy a Részes Felek megismerhessék egymás dohányzáspolitikáját, a végrehajtás aktuális állapotáról visszajelzést kapja-

\footnotetext{
iii Conference of the Parties
} 
nak, a felmerült nehézségekből és problémákból tanulhassanak. Továbbá, a jelentési rendszer segíti az egyezmény végrehajtásának nemzetközi nyomon követését. A jelentés kitöltése regisztrációhoz kötötten, online platformon történik. A jelentés két részre tagozódik: egy kötelezően megválaszolandó kérdésekből álló fő kérdőívre és egy önkéntesen kitölthető kiegészítő kérdéseket tartalmazó kérdőívre, amely 275 kérdésből áll.

A kötelező kérdőív az alábbi, az FCTC cikkeivel összhangban lévő témaköröket érinti:

\section{Jelentést készítő adatai}

- a kitöltő Részes Fél neve és elérhetőségei

- a kitöltő Részes Fél intézményének adatai és elérhetőségei

2. Dohányfogyasztás és az ehhez kapcsolódó egészségügyi, szociális és gazdasági mutatók

- a dohánytermékek használatának prevalenciája, nemenként és korcsoportonként százalékos bontásban

- a füstnélküli dohánytermékek használatának prevalenciája, nemenként és korcsoportonként százalékos bontásban

- etnikai csoportok és fiatalok dohánytermék-fogyasztásának százalékos értéke

- a dohányzás okozta halálozás adatai

- a dohányzással kapcsolatos többletköltségek

- dohánytermék kínálat

- elkobzott tiltott dohánytermékek

- dohánytermesztés

- dohánytermékek adóztatása

- dohánytermékek ára

3. Jogalkotás, szabályozás és szakpolitikák

- általános kötelezettségek

- keresletcsökkentő intézkedések

- kínálatcsökkentő intézkedések

- egyéb intézkedések és szakpolitikák

4. Nemzetközi együttmúködés és segítségnyújtás

5. Prioritások és megjegyzések
A kiegészítő kérdőív az 5. Részes Felek Konferenciájának 11 döntése alapján jött létre, amely a jelentési rendszer fejlesztéséről rendelkezik, a jelentést készítő Felekkel egyeztetve. A fent említett konferencián kiemelten foglalkoztak az információ gyűjtésével és annak megosztásával, amelyre legalkalmasabban egy olyan rendszer kifejlesztését találták megfelelőnek, amely rögzíti a felek által szolgáltatott információk összességét. A kérdőív kitöltése önkéntes, azonban bíztatják a Részes Feleket arra, hogy a kétévenkénti kötelező jelentéssel együtt kitöltsék.

A Részes Felek országjelentéseiből levont következtetések alapján a Keretegyezményhez kapcsolódó irányelvek és jegyzőkönyvek formájában továbbfejleszthető a Keretegyezmény, illetve a dohányzás-ellenőrzési nemzetközi fellépés.

\section{A JELENTÉSEKBŐL HOZZÁFÉRHETŐ ADATOK, IN- FORMÁCIÓK}

A kérdések többek között azt mérik fel, hogy a Keretegyezmény, illetve az annak végrehajtását segítő irányelvek végrehajtásában a tagállamok hogyan haladnak előre. Ennek megfelelően a kérdőívek elsősorban a vonatkozó hatályos szabályozás részleteire, statisztikai adatokra kérdeznek rá, illetve arra vonatkozó kérdéseket tartalmaznak, hogy az utolsó jelentés elkészítése óta milyen változások történtek az adott területeken.

A Részes Felek kormányai által elfogadott válaszokból létrehozott adatbázis egyedülálló lehetőséget biztosít a tagállamok által bevezetett intézkedések nyomon követésére és összehasonlítására. ${ }^{17} \mathrm{Az}$ elkészített jelentések jelentésévenkénti összehasonlítása mutatja egy adott tagállam dohányzás visszaszorítására irányuló intézkedéseit, míg az egyes intézkedések tagállamonként is összehasonlíthatóak. Jó példa erre a nemdohányzók védelmében hozott intézkedések, melyek a passzív dohányzásnak való kitettség csökkentése érdekében korlátozzák, illetve tiltják közterületen a dohányzást. [3. táblázat $]^{18}$ 
3. táblázat: A közterületeken a dohányzást teljesen tiltó országok száma és aránya WHO régiónként

\begin{tabular}{|c|c|c|}
\hline WHO régió & \multicolumn{2}{|c|}{ Országok } \\
\hline Európa & $N^{\text {iv }}$ & $\%$ \\
\hline Amerika & 9 & 17 \\
\hline Kelet-Csendes Óceán & 14 & 40 \\
\hline Dél-Kelet Ázsia & 7 & 26 \\
\hline Kelet-Mediterrán & 3 & 27 \\
\hline Afrika & 5 & 22 \\
\hline
\end{tabular}

Forrás: WHO Report on the Global Tobacco Epidemic, 2013

\section{HAZAI ADATFORRÁSOK AZ ORSZÁGJELENTÉSHEZ: EGY GYAKORLATI PÉLDA}

A WHO FCTC országjelentések alapjául szolgáló hazai ifjúsági adatokat - a dohányzási gyakoriságok tekintetében - a Nemzetközi Ifjúsági Dohányzásfelmérés (Global Youth Tobacco Survey, GYTS ${ }^{v}$ ) hazai kutatásainak eredményei adják. 2010 óta összesen 3 alkalommal vizsgáltuk részletesebben a hazai fiatalok dohányzási jellemzőit a WHO és az amerikai Betegségmegelőzési és Járványvédelmi Központ (Centers for Disease Control and Prevention - CDC) közös módszertanára alapozott GYTS felmérések keretében: a 2012-ben ${ }^{19, v i}$, 2013-ban és 2016-ban kivitelezett országosan reprezentatív kutatás kapcsán a 13-15 év közötti fiatalok dohányzási szokásait elemeztük. A GYTS a cigaretta és más dohánytermékek használatának gyakoriságáról, illetve a dohányfogyasztás meghatározó tényezőiről (hozzáférés/elérhetőség, passzív dohányzás, leszokás, média és reklám, valamint iskolai tananyag) szolgáltat adatokat. A GYTS legfrissebb eredményei alapján a nemdohányzók aránya 2012-ben 64,5\% volt a megkérdezett fiatalok körében, 2013-ra 69,5\%-ra emelkedett ez az arány, míg 2016-ban tovább nőtt 74\%ra. Az alkalmi dohányosok aránya 2012-ben 28\% volt, 2013-ban ez 21\%-ra, 2016-ban 19\%-ra csökkent. A naponta dohányzó 13-15 évesek aránya 2012-ben 7,5\% volt, 2013-ra ez az arány 9,5\%-ra emelkedett, 2016-ban pedig 6\%-ra csökkent. Ezek a kutatási adatok jelentik az országjelentés egyik legfontosabb, prevalenciával kapcsolatos részének bázisadatait.

\section{ÖSSZEGZÉS}

A dohányzás visszaszorítása országhatárokon átnyúló intézkedéseket tesz szükségessé, például a multinacionális dohányipari cégek tevékenysége és az illegális kereskedelem miatt. A WHO Dohányzásellenőrzési Keretegyezménye többek között erre is lehetőséget nyújt, ugyanakkor a Részes Felek számára az együttes fellépésen kívül a tapasztalatok és információk megosztására is mód nyílik. A kormányok által benyújtott, kétévente ismétlődő jelentések rendszerével országok szerint, régiónként, valamint globális szinten is nyomon követhetők az intézkedések és azok eredményei, a Keretegyezmény megvalósításának folyamata. A WHO FCTC titkársága a jelentések feldolgozásával és adatbázis létrehozásával segíti az adat- és információ cserét. Ez az ingyenesen hozzáférhető adatbázis lehetőséget teremt a szakemberek számára a jó gyakorlatok elterjedtségének megismerésére, valamint az új kihívások felismerésére is, így segítve a megfelelő válaszok megtalálását és azok elterjesztését.

\footnotetext{
iv Az $\mathrm{N}$ az országok számát jelöli.

v A NEFI Dohányzás Fókuszpontja által koordinált felmérést a WHO és az amerikai Betegségmegelőzési és Járványvédelmi Központ 1998-ban indította útjára. Az adatfelvételt rendszeres időközönként megismétlik a projektben résztvevő országok. Magyarországon eddig 5 alkalommal (2003, 2008, 2012, 2013, 2016) valósult meg a kutatás. A GYTS iskolai-alapú, országosan reprezentatív felmérés, amelynek mintájába 7-9. évfolyamba járó, zömmel 13-15 éves tanulók kerülnek be.

viRészletes adatok: http://www.fokuszpont.dohanyzasvisszaszoritasa.hu/sites/default/files/0 IDF Tenylap Mo VEGLEGES 20130211.pdf
} 
${ }^{1}$ http://www.who.int/mediacentre/factsheets/fs339/en/ (Elérve: 2017.01.27.)

${ }^{2}$ WHO Report on the Global Tobacco Epidemic; 2013; WHO;

http://apps.who.int/iris/bitstream/10665/85380/1/9789241505871_eng.pdf?ua=1 (Elérve: 2017.01.27.)

${ }^{3}$ http://ec.europa.eu/health/tobacco/policy hu (Elérve: 2017.02. 15.)

${ }^{4}$ http://apps.who.int/gho/data/node.sdg.3-a-viz?lang=en (Elérve: 2017. 01. 27.)

${ }^{5}$ European Tobacco Control Status Report 2013 (WHO Regional Office for Europe, 2013.)

http://www.euro.who.int/ data/assets/pdf file/0011/235973/European-Tobacco-Control-Status-Report-2013-Eng.pdf

(Elérve: 2017. 01. 27.)

${ }^{6}$ http://www.kozlonyok.hu/kozlonyok/Kozlonyok/10/PDF/2007/9.pdf (Elérve: 2017.02.01.)

7 http://www.kozlonyok.hu/nkonline/MKPDF/hiteles/mk12053.pdf (Elérve: 2017.02.01.)

${ }^{8}$ http://www.kozlonyok.hu/nkonline/MKPDF/hiteles/mk14055.pdf (Elérve: 2017.02.01.)

9 http://www.kozlonyok.hu/nkonline/MKPDF/hiteles/mk16100.pdf (Elérve: 2017.02.01.)

${ }^{10}$ U.S. National Cancer Institute and World Health Organization. The Economics of Tobacco and Tobacco Control. National Cancer Institute Tobacco Control Monograph 21. NIH Publication No. 16-CA-8029A. Bethesda, MD: U.S. Department of Health and Human Services, National Institutes of Health, National Cancer Institute; and Geneva, CH: World Health Organization; 2016. 31-34. p.

https://cancercontrol.cancer.gov/brp/tcrb/monographs/21/docs/m21 complete.pdf (Elérve: 2017. 01. 31.)

${ }_{11}$ The European Health Report 2012. WHO Regional Office for Europe, 2013.

http://www.euro.who.int/ data/assets/pdf file/0004/197113/EHR2012-Eng.pdf?ua=1 (Elérve: 2017. 01. 27.)

${ }^{12} \mathrm{~A}$ GBV projekt adatvizualizációs internetes oldala: http://vizhub.healthdata.org/gbd-compare/ (Elérve: 2017.02.20.)

${ }^{13}$ https://treaties.un.org/pages/ViewDetails.aspx?src=TREATY\&mtdsg no=IX-4\&chapter=9\&clang= en (Elérve: 2017.01.10)

${ }^{14}$ http://apps.who.int/fctc/treaty instruments/adopted/en/ (Elérve: 2017.01.31)

${ }_{15}^{15}$ http://apps.who.int/fctc/protocol/en/ (Elérve: 2017.01.31)

${ }^{16} \mathrm{http://www.fokuszpont.dohanyzasvisszaszoritasa.hu/sites/default/files/EVSZ} \mathrm{DK} \mathrm{HU.pdf} \mathrm{(Elérve:} \mathrm{2017.02.01.)}$

${ }_{17}^{17}$ http://apps.who.int/fctc/implementation/database/ (Elérve: 2017.02.03.)

${ }_{18}^{18}$ http://www.euro.who.int/ data/assets/pdf file/0011/235973/European-Tobacco-Control-Status-Report-2013Eng.pdf (Elérve: 2017.02.03.)

${ }^{19}$ Nemzetközi Ifjúsági Dohányzás Felmérés, 2012. Magyarország (13-15 éves korosztály). Tények, adatok http://www.fokuszpont.dohanyzasvisszaszoritasa.hu/sites/default/files/O IDF Tenylap Mo VEGLEGES 20130211.pdf (Elérve: 2017.03.03.) 